\title{
Effects of Dietary Xenobiotics on the Metabolism of Copper, $\alpha$-Tocopherol and Cholesterol in Rats
}

\author{
Hidehito OHCHI, Tomoko KusUHARA, Tetsuyuki KaTAYAMA, \\ Kyoko OHARA, and Norihisa KATO ${ }^{1}$ \\ Department of Applied Biochemistry, Faculty of \\ Applied Biological Science, Hiroshima University, \\ Fukuyama 720, Japan \\ (Received April 3, 1987)
}

\begin{abstract}
Summary The effects of dietary addition of some xenobiotics on tissue levels of copper and $\alpha$-tocopherol in rats were studied with special reference to serum cholesterol. The chemicals added here were $0.05 \%$ polychlorinated biphenyls (PCB), $0.3 \%$ caffeine, $0.05 \% 1,1,1$-trichloro2,2-bis( $p$-chlorophenyl)ethane (DDT), $0.3 \%$ flavone, $0.3 \%$ chloretone, $0.3 \%$ 2-tert-butyl-4-methoxyphenol (BHA), $0.15 \%$ sodium phenobarbital, $0.15 \%$ phenytoin, $0.2 \%$ sodium pentobarbital, and $0.15 \%$ phenylbutazone. Of these chemicals, dietary PCB, caffeine, DDT, flavone, chloretone, BHA and phenytoin raised the level of copper in liver, kidney, or serum. Serum $\alpha$-tocopherol and cholesterol also increased with the additive or synergistic effects on these metabolisms. Moreover, these combined addition of dietary $0.02 \%$ PCB with $0.2 \%$ BHA seemed to cause additive or synergistic effects on these metabolism. Moreover, these chemicals raised serum ceruloplasmin activity. In general, serum copper, ceruloplasmin activity and $\alpha$-tocopherol were correlated with serum cholesterol in these dietary manipulations.
\end{abstract}

Key Words xenobiotics, copper, ceruloplasmin, $\alpha$-tocopherol, cholesterol

Feeding of xenobiotics to rats results in an induction of liver microsomal drugmetabolizing enzymes and ascorbic acid synthesis (1). There is growing evidence that various xenobiotics including PCB, DDT, and caffeine cause an increase in serum cholesterol (2). These effects on cholesterol metabolism are mainly due to the induction of liver cholesterol synthesis and influenced by dietary protein and lipids (3-5).

Previously we studied the metabolism of eight trace elements in rats fed PCB and found an increment in tissue copper due to the chemical( 6 ). Recent studies by

\footnotetext{
${ }^{1}$ 黄地英仁, 楠原智子, 片山徹之, 小原匡子, 加藤範久
} 
Innami et al. indicated a raised serum $\alpha$-tocopherol in rats given PCB (7). Although studies on the underlying mechanisms of these effects are in progress, it is essential to examine whether these effects are general phenomena for a variety of xenobiotics. In the present study, we examined the influence of ten xenobiotics on these metabolisms with special reference of serum cholesterol.

Since there are many chances of chronic exposure to a variety of food chemicals, possibly through food chains, we further studied the combined effects of dietary PCB with other xenobiotics on the metabolism of copper and $\alpha$-tocopherol.

\section{MATERIALS AND METHODS}

Animals and diets. After feeding the commercial stock diet (MF, Oriental Yeast Co., Ltd., Tokyo) for 3 days, male rats of the Wistar strain weighing 50 to $60 \mathrm{~g}$ were used. The animal room was maintained at $24 \pm 1^{\circ} \mathrm{C}$ and illuminated for $12 \mathrm{~h}$ from 8:00 a.m. The basal diet was composed of $25 \%$ casein, $20 \%$ sucrose, $40 \% \alpha$ corn starch, $5 \%$ corn oil, $4 \%$ cellulose powder, $4 \%$ salt mixture $(8)$, and $2 \%$ vitamin mixture (6). The chemicals were added to the basal diet as shown in tables and figure. Deionized water and the diets were available ad libitum. After feeding the test diets for 14 to 15 days, the diets were removed from the cages at 8:00 a.m. and the animals were lightly anesthetized with ether and killed between 1:00 p.m. and 3:00 p.m. Blood was collected by heart puncture. Aliquots of blood were allowed to clot at room temperature and serum samples were isolated by centrifugation. Liver and kidney were immediately excised and weighed.

In experiments 1 and 2, influences of dietary addition of ten xenobiotics on tissue copper, $\alpha$-tocopherol, and cholesterol were studied. Experiment 3 was conducted to study the combined effect of dietary PCB with caffeine or BHA on these metabolisms.

In experiment 1 , the basal diet was supplemented with $0.05 \%$ PCB (Aroclor 1248, Mitsubishi Monsant Co., Ltd., Tokyo), $0.3 \%$ caffeine (Nakarai Chemicals Ltd., Kyoto), $0.05 \%$ DDT (Tokyo Chemical Industries Ltd., Tokyo), 0.3\% flavone (Tokyo Chemical Industries Ltd., Tokyo), $0.3 \%$ chloretone (Nakarai Chemicals Ltd., Kyoto) or $0.3 \%$ BHA (Nakarai Chemicals Ltd., Kyoto) (Table 1).

In experiment 2 , the basal diet was supplemented with $0.15 \%$ sodium phenobarbital (Wako Pure Chemical Industries Ltd., Tokyo), $0.15 \%$ phenytoin (Tokyo Chemical Industries Ltd., Tokyo), $0.2 \%$ sodium pentobarbital (Tokyo Chemical Industries Ltd., Tokyo) or $0.15 \%$ phenylbutazone (Sigma Chemical Co., Ltd., USA) (Table 2).

In experiment 3, the basal diet was supplemented with $0.02 \% \mathrm{PCB}, 0.2 \%$ caffeine, $0.2 \%$ BHA, $0.02 \%$ PCB plus $0.2 \%$ caffeine or $0.02 \%$ PCB plus $0.2 \%$ BHA (Fig. 1).

Analytical methods. Tissue levels of copper were determined by the method of McCann et al. (9). For the determination of serum copper in experiment $1,0.2 \mathrm{ml}$ sera from the animals of the same treatment groups were pooled. The copper 
contents of the experimental diets used here were found to be 12 to $13 \mu \mathrm{g}$ per $\mathrm{g}$ of the diets.

Serum $\alpha$-tocopherol was fluorometrically measured by the method of Abe and Katsui (10). Serum cholesterol was measured according to the method of Pearson et al. (11). Oxidase activity of serum ceruloplasmin [EC 1.16.3.1] was determined by the method of Schosinsky et al., in which $o$-dianisidine dihydrochloride was used as substrate (12). The activity of ceruloplasmin is expressed in International Units (in terms of substrate consumed at $30^{\circ} \mathrm{C}$ ).

Data were expressed in means \pm SE of 5 to 6 rats. Student's $t$-test was used to statistically analyze the data in experiments 1 and 2(13). In experiment 3, statistically significant differences among group means were determined by Duncan's multiple-range test (14).

\section{RESULTS}

Table 1 shows the influences of dietary xenobiotics including PCB, caffeine,

Table 1. Effects of dietary xenobiotics on tissue levels of copper and lipids (experiment 1).

\begin{tabular}{lcccc}
\hline Group & $\begin{array}{c}\text { Gains in body wt. } \\
(\mathrm{g} / 14 \text { days })\end{array}$ & $\begin{array}{c}\text { Liver wt. } \\
(\% \text { of } \\
\text { body wt. })\end{array}$ & $\begin{array}{c}\text { Liver Cu } \\
(\mu \mathrm{g} / \mathrm{g} \text { tissue })\end{array}$ & $\begin{array}{c}\text { Kidney wt. } \\
(\% \text { of } \\
\text { body wt. })\end{array}$ \\
\hline Control & $102 \pm 4^{\mathrm{b}}$ & $4.68 \pm 0.14$ & $3.3 \pm 0.2$ & $0.88 \pm 0.03$ \\
$0.05 \%$ PCB & $94 \pm 2$ & $7.40 \pm 0.15^{*}$ & $5.3 \pm 0.2^{*}$ & $1.02 \pm 0.03^{*}$ \\
$0.3 \%$ Caffeine & $59 \pm 3^{*}$ & $4.70 \pm 0.15$ & $4.4 \pm 0.1^{*}$ & $1.06 \pm 0.04^{*}$ \\
$0.05 \%$ DDT & $95 \pm 5$ & $6.17 \pm 0.23^{*}$ & $4.3 \pm 0.2^{*}$ & $1.17 \pm 0.21^{*}$ \\
$0.3 \%$ Flavone & $62 \pm 6^{*}$ & $7.25 \pm 0.25^{*}$ & $4.2 \pm 0.2^{*}$ & $1.27 \pm 0.05^{*}$ \\
$0.3 \%$ Chloretone & $111 \pm 5$ & $5.46 \pm 0.12^{*}$ & $3.9 \pm 0.3$ & $1.07 \pm 0.02^{*}$ \\
$0.3 \%$ BHA & $101 \pm 3$ & $5.29 \pm 0.13^{*}$ & $3.4 \pm 0.1$ & $0.95 \pm 0.02$ \\
\hline & & & Serum & Serum \\
Group & Kidney Cu & Serum Cu & $\alpha-$ tocopherol & cholesterol \\
& $(\mu \mathrm{g} / \mathrm{g}$ tissue $)$ & $(\mu \mathrm{g} / 100 \mathrm{ml})$ & $(\mathrm{mg} / 100 \mathrm{ml})$ & $(\mathrm{mg} / 100 \mathrm{ml})$ \\
\hline Control & $4.0 \pm 0.1$ & $97^{\mathrm{c}}$ & $1.72 \pm 0.36$ & $62 \pm 5$ \\
$0.05 \%$ PCB & $12.4 \pm 2.8^{*}$ & 130 & $6.73 \pm 0.46^{*}$ & $129 \pm 8^{*}$ \\
$0.3 \%$ Caffeine & $16.0 \pm 2.2^{*}$ & 144 & $3.19 \pm 0.48^{*}$ & $96 \pm 5^{*}$ \\
$0.05 \%$ DDT & $5.8 \pm 0.6^{*}$ & 119 & $3.89 \pm 0.60^{*}$ & $87 \pm 11^{*}$ \\
$0.3 \%$ Flavone & $4.5 \pm 0.3$ & 136 & $3.23 \pm 0.22^{*}$ & $138 \pm 8^{*}$ \\
$0.3 \%$ Chloretone & $4.4 \pm 0.1^{*}$ & 123 & $5.22 \pm 1.03^{*}$ & $116 \pm 8^{*}$ \\
$0.3 \%$ BHA & $13.7 \pm 3.4^{*}$ & 117 & $3.78 \pm 0.62^{*}$ & $113 \pm 5^{*}$ \\
\hline
\end{tabular}

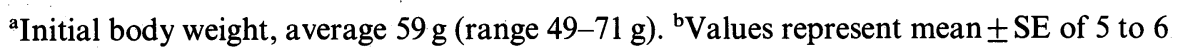

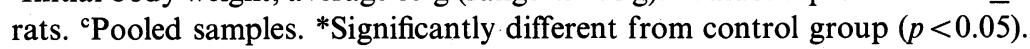

Vol. 33, No. 4, 1987 
DDT, flavone, chloretone and BHA on weight gain, tissue copper, serum $\alpha$ tocopherol, and serum cholesterol. A retardation of the growth was observed in the caffeine- or flavone-fed animals as compared with control group. Liver weight increased with the chemicals except caffeine. Dietary addition of PCB, caffeine, DDT, and flavone caused a significant increase in liver concentration of copper, but dietary chloretone and BHA did not. Kidney copper significantly increased with the intake of PCB, caffeine, DDT, chloretone and BHA. All the chemicals examined here caused an increase in serum copper, $\alpha$-tocopherol, and cholesterol (Table 1). Serum copper and $\alpha$-tocopherol generally correlated with serum cholesterol.

Table 2 represents the data on the influences of dietary phenobarbital, phenytoin, pentobarbital, and phenylbutazone on weight gain, tissue copper, serum $\alpha$-tocopherol, and serum cholesterol. The weight gain was not affected by the chemicals. Liver enlargement was observed only in phenobarbital-treated animals. Dietary phenytoin significantly raised liver copper, but the other chemicals did not

Table 2. Effects of dietary xenobiotics on tissue levels of copper and lipids (experiment 2).

\begin{tabular}{|c|c|c|c|c|}
\hline Group & $\begin{array}{l}\text { Gains in body wt. }{ }^{\mathrm{a}} \\
\text { (g/14 days) }\end{array}$ & $\begin{array}{l}\text { Liver wt. } \\
(\% \text { of } \\
\text { body wt.) }\end{array}$ & $\begin{array}{c}\text { Liver } \mathrm{Cu} \\
(\mu \mathrm{g} / \mathrm{g} \text { tissue })\end{array}$ & $\begin{array}{l}\text { Kidney wt. } \\
\text { (\% of } \\
\text { body wt.) }\end{array}$ \\
\hline \multirow{5}{*}{$\begin{array}{l}\text { Control } \\
0.15 \% \text { Sodium } \\
\text { phenobarbital } \\
0.15 \% \text { Phenytoin } \\
0.2 \% \text { Sodium } \\
\text { pentobarbital } \\
0.15 \% \text { Phenyl- } \\
\text { butazone }\end{array}$} & $100 \pm 4^{b}$ & $5.05 \pm 0.20$ & $2.8 \pm 0.1$ & $1.00 \pm 0.03$ \\
\hline & $98 \pm 4$ & $6.25 \pm 0.26^{*}$ & $3.3 \pm 0.3$ & $1.02 \pm 0.02$ \\
\hline & $89 \pm 2$ & $5.29 \pm 0.33$ & $3.2 \pm 0.1^{*}$ & $1.00 \pm 0.02$ \\
\hline & $106 \pm 1$ & $5.49 \pm 0.10$ & $3.1 \pm 0.2$ & $1.03 \pm 0.01$ \\
\hline & $99 \pm 1$ & $5.53 \pm 0.23$ & $2.9 \pm 0.1$ & $1.11 \pm 0.04$ \\
\hline Group & $\begin{array}{l}\text { Kidney } \mathrm{Cu} \\
(\mu \mathrm{g} / \mathrm{g} \text { tissue })\end{array}$ & $\begin{array}{l}\text { Serum } \mathrm{Cu} \\
\mu \mathrm{g} / 100 \mathrm{ml})\end{array}$ & $\begin{array}{c}\text { Serum } \\
\alpha \text {-tocopherol } \\
(\mathrm{mg} / 100 \mathrm{ml})\end{array}$ & $\begin{array}{c}\text { Serum } \\
\text { cholesterol } \\
(\mathrm{mg} / 100 \mathrm{ml})\end{array}$ \\
\hline \multirow{4}{*}{$\begin{array}{l}\text { Control } \\
0.15 \% \text { Sodium } \\
\text { phenobarbital } \\
0.15 \% \text { Phenytoin } \\
0.2 \% \text { Sodium } \\
\text { pentobarbital }\end{array}$} & $4.3 \pm 0.2$ & $114 \pm 5$ & $2.57 \pm 0.18$ & $86 \pm 5$ \\
\hline & $4.3 \pm 0.3$ & $144 \pm 4^{*}$ & $6.13 \pm 0.43^{*}$ & $114 \pm 11^{*}$ \\
\hline & $4.4 \pm 0.5$ & $102 \pm 7$ & $3.51 \pm 0.37$ & $89 \pm 18$ \\
\hline & $5.8 \pm 1.0$ & $121 \pm 5$ & $3.81 \pm 0.38^{*}$ & $97 \pm 4$ \\
\hline $\begin{array}{l}0.15 \% \text { Phenyl- } \\
\text { butazone }\end{array}$ & $4.1 \pm 0.3$ & $91 \pm 5$ & $2.71 \pm 0.52$ & $75 \pm 5$ \\
\hline
\end{tabular}

${ }^{\mathrm{a}}$ Initial body weight, average $59 \mathrm{~g}$ (range $50-70 \mathrm{~g}$ ). ${ }^{\mathrm{b}}$ Values represent mean $\pm \mathrm{SE}$ of 6 rats. *Significantly different from control group $(p<0.05)$. 

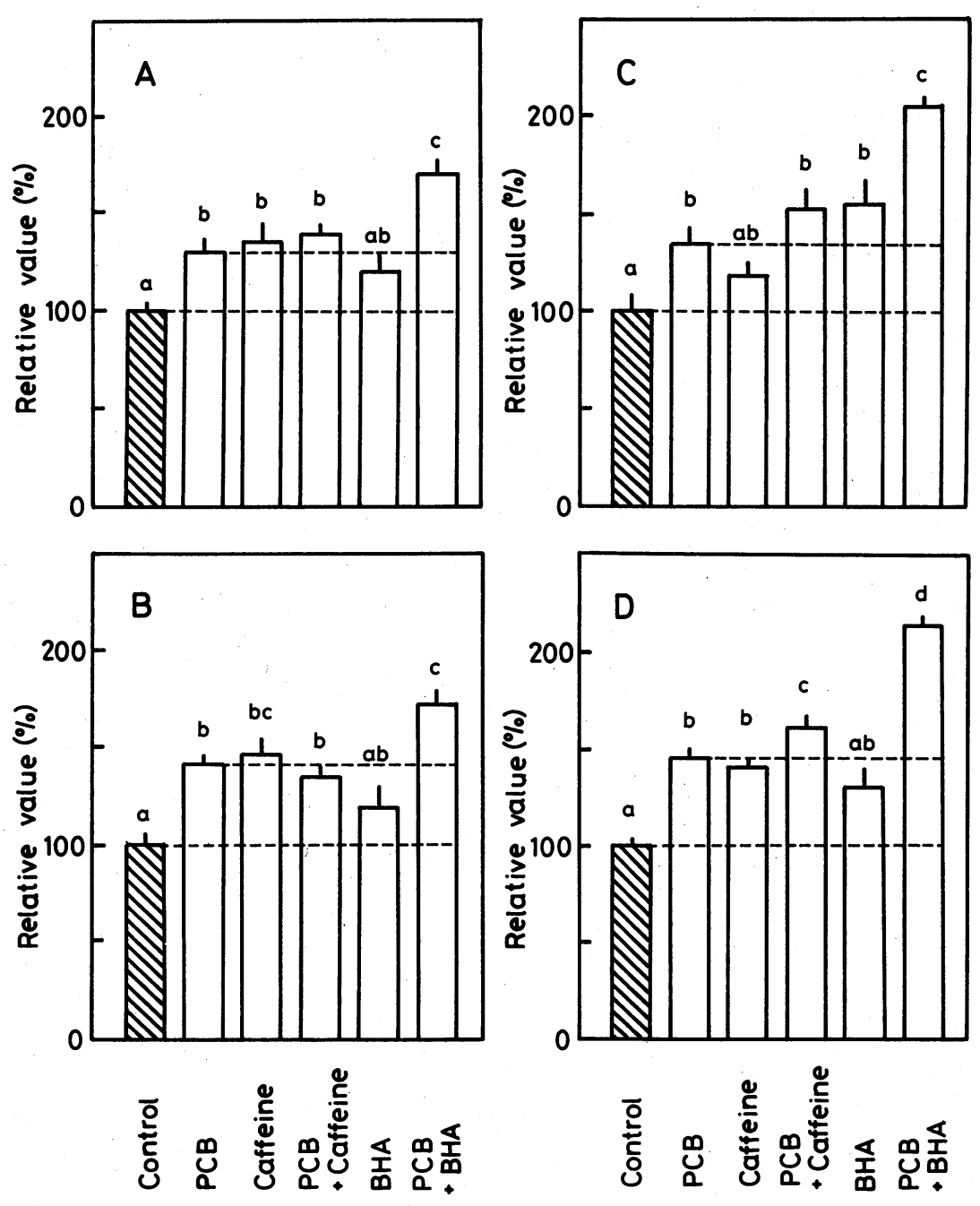

Fig. 1. Combined effects of dietary $0.02 \%$ PCB with $0.2 \%$ caffeine or $0.2 \%$ BHA on serum copper, ceruloplasmin activity, $\alpha$-tocopherol and cholesterol (experiment 3 ). A, serum copper; B, ceruloplasmin activity; C, serum $\alpha$-tocopherol; D, serum cholesterol. Values of control group in serum copper, ceruloplasmin activity, $\alpha-$ tocopherol, and cholesterol were $84 \mu \mathrm{g}, 8.1$ units, $1.74 \mathrm{mg}$, and $77 \mathrm{mg}$ per $100 \mathrm{ml}$, respectively. Values not sharing a common letter are significantly different $(p<0.05)$.

at these dietary levels. Kidney copper was hardly affected by the chemicals. Serum copper and cholesterol were increased with phenobarbital intake. Phenobarbital and pentobarbital intake significantly raised serum $\alpha$-tocopherol. As in experiment 1 , serum copper and $\alpha$-tocopherol generally correlated with serum cholesterol.

The combined effects of dietary PCB with caffeine or BHA on serum copper, Vol. 33, No. 4, 1987 
ceruloplasmin, $\alpha$-tocopherol, and cholesterol were presented in Fig. 1 . In this experiment, a retardation of the growth was observed in the caffeine group $(32 \%$ reduction), but not in other groups. Serum copper, ceruloplasmin activity, $\alpha$ tocopherol, and cholesterol were generally increased with dietary addition of these chemicals. The combined effect of dietary PCB with caffeine on serum $\alpha$-tocopherol was additive, but the effects on other serum parameters were not. The effects of dietary PCB with BHA on these parameters seemed to be additive or synergistic. Serum cholesterol significantly correlated with serum copper $(r=0.72, p<0.05)$ and with serum $\alpha$-tocopherol $(r=0.67, p<0.05)$. Notice a good correlation between serum copper and ceruloplasmin activity $(r=0.85, p<0.05)$.

\section{DISCUSSION}

We previously reported that dietary addition of PCB raised tissue copper (6). In the present study; it was demonstrated that feeding of six other xenobiotics including caffeine, DDT, flavone, chloretone, BHA, and phenytoin also caused an increase in liver, kidney, or serum copper (Tables 1 and 2). During our study, Dubick and Keen also reported an increase in tissue copper of rats fed phenytoin(15). Thus, it seems likely that these effects could be widely observed for a variety of xenobiotics.

It has been reported that changes in tissue levels of copper metalloenzymes such as ceruloplasmin, cytochrome $c$ oxidase and superoxide dismutase were induced by varying levels of dietary copper $(16,17)$. Since previous study indicated no influence of dietary PCB on the activities of cytochrome $c$ oxidase and superoxide dismutase in liver and kidney (unpublished data), an attempt was made here to examine the activity of serum ceruloplasmin. The result clearly showed a raised activity of serum ceruloplasmin by xenobiotics. In addition, there was a good correlation between serum copper and ceruloplasmin activity (Fig. 1). Frieden has divided ceruloplasmin's potential functions into five categories: 1) oxidation of $\mathrm{Fe}^{2+}$ as it is released from hepatocytes and converted to $\mathrm{Fe}^{3+}$-transferrin in the regulation of hepatic iron mobilization; 2) oxidase activity for aromatic amines; 3 ) transport of copper to tissue sites; 4) serum antioxidation, in which it acts as a scavenger of free radicals and superoxide ion; and 5) endogenous modulation of the inflammatory responses (18). Some of these functions of ceruloplasmin may relate to the adaptive response to the intake of xenobiotics.

The present study further showed a raised serum $\alpha$-tocopherol in animals fed xenobiotics. It is well known that administration of xenobiotics to rats causes an increase in the synthesis of ascorbic acid, which in turn results in the increased tissue and urinary ascorbic acid(1). Studies by Kobayashi and Yoshida indicated cooperative interaction of $\alpha$-tocopherol and ascorbic acid in suppression of lipid peroxidation induced by PCB feeding to guinea pigs and an increment in the requirement of $\alpha$-tocopherol due to $\operatorname{PCB}(19)$. We speculate that the increase in serum ceruloplasmin and $\alpha$-tocopherol may relate to the suppression of lipid 
peroxidation induced by xenobiotics.

It has been shown that the activity of liver microsomal drug-metabolizing enzymes in animals given xenobiotics correlated with serum cholesterol and urinary ascorbic acid (2). The present study demonstrated that serum cholesterol generally correlated with serum copper and $\alpha$-tocopherol when the animals were fed xenobiotics. Although the physiological significance of these metabolic interrelationships is unknown, it is tempting to postulate that inducers of drugmetabolizing enzymes might generally have potential functions to raise serum cholesterol, copper, and $\alpha$-tocopherol. It has been reported that hypercholesterolemia could be induced by feeding the diet deficient in copper or vitamin $\mathrm{E}(20,21)$. These facts together with the present study emphasize an importance of the metabolic interrelationship among copper, vitamin E, and cholesterol.

We further observed additive or synergistic effects of dietary PCB with BHA on these metabolisms (Fig. 1). This result is noteworthy because there are various xenobiotics in the environment around us today.

The present study demonstrated that xenobiotics are a possible factor affecting the nutritional status of copper and $\alpha$-tocopherol. Further studies are in progress on the underlying mechanisms and on the physiological significance of these metabolic responses.

\section{REFERENCES}

1) Kato, N., and Yoshida, A. (1979): Effects of some fat-soluble chemicals on plasma cholesterol and urinary ascorbic acid in rats. Agric. Biol. Chem., 43, 191-192.

2) Kato, N., and Yoshida, A. (1980): Effects of dietary xenobiotics on serum total cholesterol and high density lipoprotein cholesterol in rats. Nutr. Rep. Int., 23, 825-831.

3) Nagaoka, S., Masaki, H., Aoyama, Y., and Yoshida, A. (1986): Effects of excess dietary tyrosine or certain xenobiotics on the cholesterogenesis in rats. J. Nutr., 116, 726-732.

4) Kato, N., Tani, T., and Yoshida, A. (1981): Effect of dietary level of protein on liver microsomal drug-metabolizing enzymes, urinary ascorbic acid and lipid metabolism in rats fed PCB-containing diets. J. Nutr., 110, 1686-1694.

5) Quazi, S., and Yoshida, A. (1985): Influence of unsaturated and saturated fats on lipid metabolism in rats fed either PCB or cholesterol. Nutr. Rep. Int., 31, 535-546.

6) Ohchi, H., Gunshin, H., Katayama, T., and Kato, N. (1986): Effect of dietary PCB on the metabolism of eight trace elements (iron, zinc, copper, manganese, molybdenum, chromium, nickel and cobalt) in rats. Nutr. Rep. Int., 33, 157-162.

7) Innami, S., Ikegami, S., Saito, M., Nakamura, A., and Nagayama, S. (1982): Lack of responsibility of lipid peroxidation for reduction of vitamin $\mathrm{A}$ in the liver of rats given polychlorinated biphenyls. Nutr. Rep. Int., 25, 931-940.

8) Ebihara, K., Imamura, Y., and Kiriyama, S. (1979): Effect of dietary mineral composition on nutritional equivalency of amino acid mixture and casein in rats. $J$. Nutr., 109, 2106-2116.

9) McCann, D. S., Burcar, P., and Boyle, A. J. (1960): Rubeanic acid for determination of copper in human serum. Anal. Chem., 32, 547-550.

10) Abe, K., and Katsui, G. (1975): Fluorometric determination of tocopherol in serum. $J$. Jpn. Soc. Nutr. Food Sci., 28, 277-280.

Vol. 33, No. 4, 1987. 
11) Pearson, S., Stern, S., and McGavack, T. H. (1953): A rapid, accurate method for the determination of total cholesterol in serum. Anal. Chem., 25, 813-814.

12) Schosinsky, K. H., Lehmann, H. P., and Beeler, M. F. (1974): Measurement of ceruloplasmin from its oxidase activity in serum by use $o$-dianisidine dihydrochloride. Clin. Chem., 20, 1556-1563.

13) Snedecor, G. W., and Cochran, W. G. (1967): Statistical Methods, 6th Ed., The Iowa State University Press, Ames, IA (Japanese translated edition; Iwanami Publ. Inc., Tokyo).

14) Duncan, D. B. (1955): Multiple range and multiple F test. Biometrics, 11, 1-6.

15) Dubick, M. A., and Keen, C. L. (1985): Alterations in tissue trace element and ascorbic acid metabolism in phenytoin-fed rats and mice. J. Nutr., 115, 1481-1487.

16) Paynter, D. I., Moir, R. J., and Underwood, E. J. (1979): Changes in activity of the Cu$\mathrm{Zn}$ superoxide dismutase enzyme in tissue of the rat with changes in dietary copper. $J$. Nutr., 109, 1570-1576.

17) Owen, C. A., Jr., and Hazelrig, J. B. (1968): Copper deficiency and copper toxicity in the rats. Am. J. Physiol., 215, 334-338.

18) Frieden, E. (1980): Ceruloplasmin: a multi-functional metalloprotein of vertebrate plasma, in Biological Roles of Copper (Ciba Found. Symp.), Elsevier/North-Holland, Amsterdam and New York, pp. 93-124.

19) Kawai-Kobayashi, K., and Yoshida, A. (1986): Effect of dietary ascorbic acid and vitamin $\mathrm{E}$ on metabolic changes in rats and guinea pigs exposed to PCB. J. Nutr., 116, 98-106.

20) Lei, K. Y. (1977): Cholesterol metabolism in copper deficient rats. Nutr. Rep. Int., 15, 597-605.

21) Westrope, K. L., Miller, R. A., and Wilson, R. B. (1982): Vitamin E in a rabbit model of endogeneous hypercholesterolemia and atherosclerosis. Nutr. Rep. Int., 25, 83-88. 